\title{
A traumatikus élmények facilitáló szerepe a múvészetben
}

\author{
Gerevich József dr.
}

Addiktológiai Kutató Intézet, Budapest

\begin{abstract}
Traumatikus élmények nemcsak kedvezőtlen következményekkel járhatnak, hanem a traumában érintett személyek fejlődéséhez is hozzájárulhatnak. Ebben a tanulmányban hat traumatípust vizsgáltam meg különböző festmények és az élettörténet elemzése révén: érzelmi depriváció/elhanyagolás, halálközeli élmény, erőszak áldozatává válás, háború, baleset/betegség és érzelmi frusztráció. A képzőmúvészeti alkotások felhívhatják a figyelmet alkotójuk traumatikus élményeire gyakran ismétlődő motívumokkal és ábrázolástechnikával (Nap, anyakép, az elveszített személyre utaló tárgyak, erőszakos vagy az erőszakot jelképező motívumok, felduzzadt énkép múvészi megnyilvánulásai, szürreális víziók, fanyar irónia, a szeretett személy más tárgyakkal való helyettesítése), illetve hirtelen stílus- és témaváltás, amely az emberi szenvedés iránt megmutatkozó fokozott érdeklődést fejezheti ki (Lovis Corinth). Az önábrázolás hangsúlyos jellege az alkotó fokozott önvizsgálatára, esetleg betegsége, lelkiállapota folyamatos monitorozására utalhat (Frida Kahlo, Otto Dix, Lovis Corinth, Edvard Munch). A művészi tevékenység egyes esetekben hozzájárulhat a trauma feldolgozásához (Hans Bellmer, Oskar Kokoschka, Max Ernst, René Magritte), más esetben nem képes meggátolni a trauma pszichológiai/pszichiátriai következményeinek kialakulását (Artemisia Gentileschi, Edvard Munch, Gulácsy Lajos). Orv Hetil. 2017; 158(17): 668-677.
\end{abstract}

Kulcsszavak: trauma, múvészet, érzelmi depriváció/elhanyagolás, elhúzódó gyász, percipiált poszttraumás kreatív növekedés

\section{Facilitating role of traumatic experiences in art}

Traumatic experiences can not only have unfavourable consequences, they can also contribute, with a kind of creative twist, to the development of the person affected by the trauma. The artistic responses to traumas can be examined on the basis of the different types of trauma. This study reports on an investigation focusing on six types of trauma: emotional deprivation/neglect; near-death experience; becoming the victim of violence; war; accident/sickness and emotional frustration. Examples taken from the history of art indicate that works of art can draw attention to the traumatic experiences of the artists with frequently repeated motifs and portrayal techniques (sun, mother image, objects referring to the person lost, motifs of violence or symbols of violence, artistic manifestations of an exaggerated self-image, surreal visions, dry irony, substituting other objects for the beloved person), or a sudden change of style and subject that can express a heightened interest in human suffering (Lovis Corinth). An emphasis placed on self-portrayal can indicate the artist's increased self-examination, in cases of sickness, or continuous monitoring of the state of mind (Frida Kahlo, Otto Dix, Lovis Corinth, Edvard Munch). In some cases artistic activity can help to work through the trauma (Hans Bellmer, Oskar Kokoschka, Max Ernst, René Magritte), in other cases it is not able to prevent the development of psychological/psychiatric consequences of the trauma (Artemisia Gentileschi, Edvard Munch, Lajos Gulácsy). Traumas can be the sources of motivation and provide themes for works of art; and, although not in all cases, artistic creativity can contribute to effectively working through traumatic experiences.

Keywords: trauma, art, emotional deprivation/neglect, long-lasting grief, perceived posttraumatic creative growth

Gerevich J [Facilitating role of traumatic experiences in art]. Orv Hetil. 2017; 158(17): 668-677.

(Beérkezett: 2017. március 3.; elfogadva: 2017. március 23.) 


\section{„A trauma növeli a szubjektivitás szerepét a müvészetben." (Lajtai Péter)}

A görög/latin eredetû 'trauma' kifejezés a személyt hirtelen érő erôszakos testi vagy lelki hatást jelöli. Egy esemény akkor válik traumatikussá, ha a benne részt vevő személyek valamelyike a halál, súlyos sérülés vagy az én fizikai integritásának fenyegetettségét éli át vagy tanúként észleli másokét. Ebben a definícióban az esemény szubjektív átélésének intenzitása fontos hangsúlyt kap. A trauma lehet egyszeri vagy ismétlődő, kapcsolódhat természeti vagy ember által kiváltott katasztrófához (például cunami vagy bombázás), bekövetkezhet szándékosan vagy akaratlanul (például szexuális erőszak, autókarambol vagy súlyos betegség). A traumának való átmeneti kitettség nem látható ártalmakhoz vezethet vagy ellenkezőleg: manifeszt pszichológiai, pszichiátriai ártalmakat válthat ki, mint például a szorongásos zavar valamelyik formája, beleértve a poszttraumás stresszzavart, vagy depresszió, az úgynevezett externalizáló betegségek és tünetek (acting out, agresszív és impulzív viselkedés), vagy az úgynevezett internalizáló betegségek és tünetek (visszahúzódás, deprimált vagy félelemteli viselkedés), öngyilkossági kísérlet vagy befejezett öngyilkosság, szerabúzus, gyászreakció. A traumára adott válaszok kialakulhatnak közvetlenül a trauma után vagy hetekkel, hónapokkal később [1]. A traumatikus esemény viszonylagosságára utal az a körülmény, hogy vannak, akik (látszólag vagy valóságosan) életveszélyes állapotokat sem élnek meg traumaként, míg mások - más által jelentéktelennek tünő - eseményre a traumákra jellemző súlyos válaszokkal reagálnak. A pszichoanalitikus traumairodalom a feldolgozatlan trauma egész életen át tartó hatásaira hívja fel a figyelmet [2-4].

Másodlagos traumáról akkor beszélünk, ha hétköznapi helyzetre (például a másik fél kilépésére a partnerkapcsolatból) adott válasz messze túllépi az egészségesség határait, azt sugallva, hogy a személyiség korábban már találkozott hasonló helyzettel, s az azzal való megbirkózáshoz, kellő érettség hiányában, nem rendelkezett megfelelő eszközzel, és az ismételten jelentkező helyzet ugyanolyan felkészületlenül éri, mert az első, primer trauma feldolgozása elmaradt.

A kreativitásirodalomban a trauma fogalmát tágabb gyưjtőkifejezésbe helyezve tárgyalják, adverzitásról, viszontagságról, balsorsról beszélnek (adversity). Negatív életesemények, pszichológiai-pszichiátriai, valamint testi, fizikai betegségek alkotják a viszontagságok körét [5]. A pszichiátriai következmények a múvészek között leggyakrabban költőnők körében figyelhetők meg, emiatt ezt a jelenséget Sylvia Plath-effektusnak is nevezik [6]. A trauma, traumatikus élmény kifejezés azért pontosabb, mert használatával elkülöníthetővé válnak az okok, az oki, prediktív tényezók, illetve a trauma által kiváltott okozatok, következmények. Ezért is terjedt el a percipiált poszttraumás kreatív növekedés (perceived posttraumatic creative growth) fogalma $[5,7]$.
Míg a trauma kedvezőtlen hatásai jól ismertek, kevesebb az adat a trauma lehetséges kedvező kimeneteléról [8]. Traumatikus élményen átesettek beszámoltak arról, hogy a traumát követően javultak az interperszonális kapcsolataik, nőtt az önbizalmuk és céltudatosabbak lettek [9]. Joggal vetődik fel a kérdés, vajon a trauma után megfigyelhető kedvező fejlemények hozzájárulhatnak-e a múvészi kreativitás fejlődéséhez, múalkotások születéséhez. Számos kreatív személyiség élettörténete kínál példát erre. Frida Kahlo mexikói festő gyermekbénulást és súlyos autóbusz-balesetet követően vált generációja egyik legkiemelkedőbb múvészévé. Johann Sebastian Bach kilencéves korában jutott árvaságra, majd gigantikus zenei életmúvet alkotott. Robert Louis Stevenson skót író egész életében rossz fizikai egészségtől és krónikus depressziótól szenvedett. A kutatók megegyeznek abban, hogy a kreatív emberek képessé válhatnak arra, hogy negatív élettapasztalataikat munkájuk inspirációjába kanalizálják, és a kreativitást, mint megküzdési (coping) stratégiát alkalmazzák a nehézségek legyôzésére [10]. Az összefüggések azonban ennél is bonyolultabbak.

Traumatikus élmények mûvészi alkotások motivációs forrásai és témái lehetnek; a múvészi kreativitás pedig hozzájárulhat, de nem minden esetben, traumatikus élmények hatékony feldolgozásához [10]. Ebben a tanulmányban múvészettörténeti példákon keresztül mutatom be, hogy a traumatikus élmények hogyan facilitálják a müvészi tevékenységet. A következő traumatípusokkal találkoztam a téma feldolgozásakor: érzelmi depriváció és elhanyagolás, halálközeli élmény (közvetlen hozzátartozó halála, életveszélyes helyzetek túlélése), erőszak áldozatává válás, háborús trauma, betegség/baleset, szerelmi frusztráció (másodlagos traumaként). A holokauszt traumája nem szerepel a vizsgált témák között, egy későbbi kutatás tárgyaként külön tanulmány feladata lesz. Az egyes traumatípusok élesen nem választhatók külön egymástól, vannak átfedések: a hozzátartozó korai halála és az érzelmi depriváció akár ok-okozati összefüggésben is lehet. Didaktikai okokból viszont érdemes külön tárgyalni a két traumatípust.

\section{Érzelmi depriváció és elhanyagolás}

Az érzelmi környezet hiánya szélsőséges esetekben megölheti a csecsemőket, amint a romániai árvaház kis lakóinak a kilencvenes években észlelt tragikus példája is mutatja. A fizikailag ellátott csecsemók többsége az érzelmi kontaktus hiánya miatt halt meg. Azok élték túl az áldatlan helyzetet, akik közel voltak az ajtóhoz, és a takarítónők szóltak hozzájuk, esetleg megsimogatták őket [11]. Az árvaházi érzelemhiány és a tökéletes érzelmi telítettség között széles sáv húzódik. Az érzelmi depriváció és elhanyagolás fogalomköre a fejlődés korai, sorsdöntő időszakainak érzelmi nélkülözését jelöli, amelyre, mint folyamatos traumatizációra, kétféleképpen reagálhat a fejlődésben lévő gyermek: vagy visszahúzódik és elfojtja 
érzelmi szükségleteit, vagy újra és újra traumaként éli meg azt. Azok a múvészek, akiknek biográfiai elemzése része e tanulmánynak, az utóbbiak közé tartoznak.

Az érzelmi depriváció és művészet kapcsolatához kétféleképpen közelíthetünk. A múvekből kiindulva hipotézist állíthatunk fel arról, hogy egyes festmények alapján az élettörténetben igazolható-e az érzelmi depriváció problémája vagy fordítva, az élettörténetben dokumentált érzelmi depriváció nyomait keressük az életmúvön. E tanulmányban mindkét megközelítést alkalmazzuk.

Vincent van Gogh, Csontváry Kosztka Tivadar és Gulácsy Lajos, a három Nap-festő képein a Nap, a fény, a színek ragyogása felveti annak gyanúját, hogy mindhárman egyfajta vágyteljesítő célzattal, azaz érzelmi nélkülözésük ellensúlyozására alkalmazták a meleg, sugárzó színeket. Van Gogh például Rembrandt festményét, a Lázár feltámasztását másolva az eredeti képből kiretusálta Krisztus alakját és a napkoronggal helyettesítette azt, jelezve, hogy Lázárt a Nap melege támasztotta fel. Arles-i házának falát sárgára, a Nap színére festette. Egyes képein a Nap különös izzása arra utal, hogy számára a Nap lefestése öngyógyító mozzanat lehetett, a festett égitest „felmelegítette” őt (1. ábra).

Van Goghhoz hasonlóan, Csontváry és Gulácsy is déli tájakra vándorolt. A Nap melegére volt szükségük az ihlethez, a festés egyfajta rituális kellékeként. Élettörténetük elemzése emocionális anyaproblémára utal. Míg más festők (például Gauguin, Lautrec, Modigliani, Dalí) anyja hangsúlyosan van jelen az élettörténetben, van Gogh és Csontváry anyját sűrű homály fedi. A magát „Nap-útfestőként” azonosító Csontváryt dajka nevelte, „... mint kis gyermek, dajkám öléból csodáltam a nagy üstököst”. Miltényi [12] szerint „Csontváryt egy kisgyerekkori trauma tette magányossá. Vélhetően szerelmes volt a dajkájába, aki valahogy visszaélt ezzel a helyzettel!" Miltényi forrása maga a festő, aki az Energia és múvészet címü írása Ki lehet zseni fejezetében írja a következőket: „zseni lehet... aki szerelmes volt a dajkájába....", majd a Tekintély címú írásában: „... így élve éldegélsz s áhítozva tekintesz vissza a régmúlt időkre - nem a kéjelgő dajkákra, kéjelgéssel altatott éjszakákra..." Gulácsy emocionális anyaproblémája patográfiájában jól dokumentált [13]. Mindhármuk érzelmi deprivációja nőmentes életbe torkollott, amelytől van Gogh egész életében szenvedett, míg Csontváry és Gulácsy másként reagálta le ezt. Gulácsy pályája elején - egyfajta vágyteljesítő fantáziaként - nagy beleérzéssel szerelmespárokat ábrázolt, Csontváry pedig önéletrajzában a maga sajátos módján deklarálta, hogy őt gyermekkorában „elválasztották örökre” a nőktől, és soha ezzel a témával a későbbiekben nem foglalkozott.

A rideg dajka problémája Frida Kahlo egyik legmegrázóbb képén is megjelenik ( $A$ dajkám és én, 1937), ahol egy marcona dajkamonstrum tartja karjaiban Fridát, akinek szája a szörny emlőjére tapad (2. ábra). Anyja hideg, elutasító magatartásának hatása a Születésem vagy születés (1932) című drámai képben is megnyilvánult, ahol a fes-

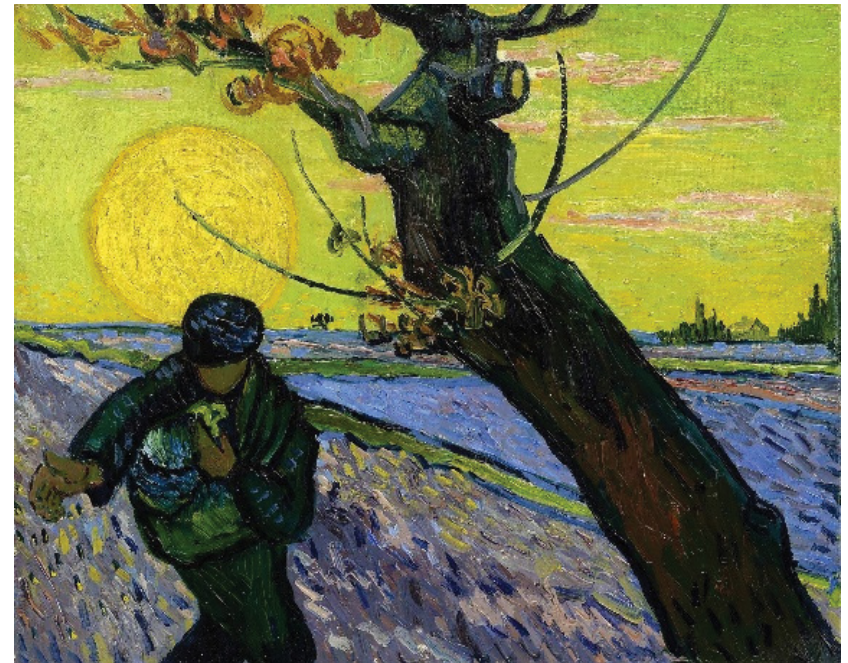

1. ábra $\quad$ Vincent van Gogh: Magvetó, 1888

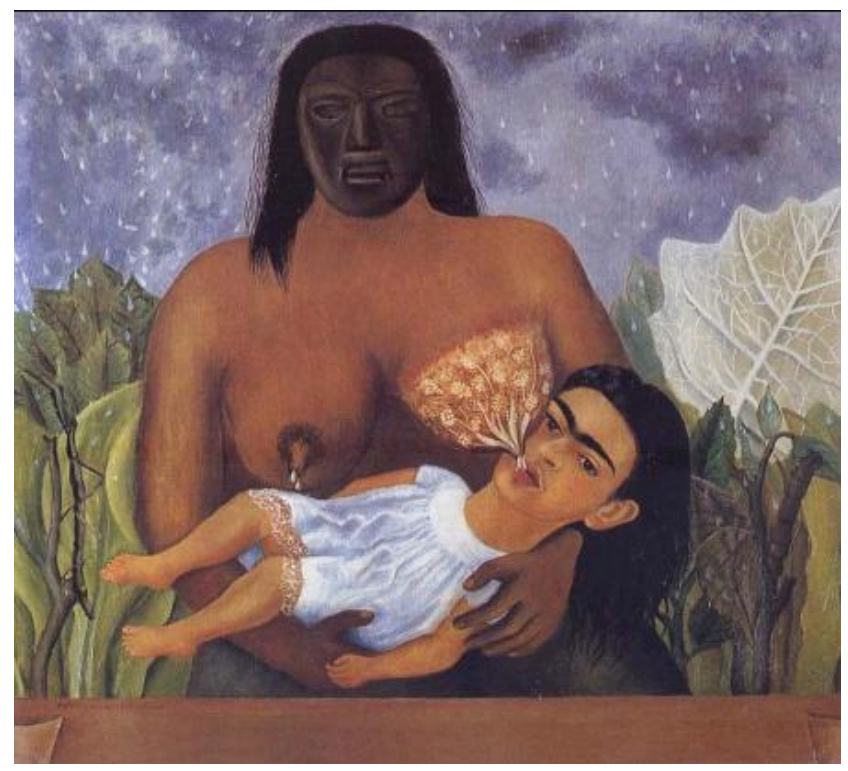

2. ábra

| Frida Kahlo: A dajkám és én, 1937

tőnő egy széles ágyon megszüli önmagát, szemben anyja falon lógó képmásával.

Egon Schiele egész életében konfliktusban állt az anyjával. „Az anyám nagyon furcsa asszony... A legkevésbé sem ért meg engem, snem is nagyon szeret. Ha lenne benne szeretet vagy megértés, kész lenne áldozatokat hozni" - írja egyik levelében. Más alkalommal ezt írja: „Az én anyám, akire sok tulajdonságban hasonlitok, akivel egy hús és vér vagyok... sokszor úgy áll velem szemben, mint idegen az idegennel szemben. Ez engem nagyon bánt." 1908 és 1910 között sorozatnyi festményt, grafikát készít az anyatémáról (Anya a gyermekével, Halott anya, A zseni születése, A terbes nó és a halál, Vak anya, Fiatal anya [Vak anya II.], Mostohaanya), amelyek anyjával szembeni vádiratként a vak, szeretet nélküli, „mostoha” anyaságról vallanak [10].

A társas környezetben észlelt érzelmi hárítás élménye kreatív gondolkodásra serkentheti a hárítást elszenvedő- 
ket; a másoktól való különbözőség érzésének hangsúlyos megjelenése környezettől független, nem interdependens szelfképet alakít ki [14].

\section{Halálközeli élmény}

\section{Közvetlen hozzátartozó halála}

Tehetséges, magas kreatív képességekkel rendelkező személyek, az átlagemberekhez képest, gyakrabban tapasztalják meg gyermekkorukban közvetlen hozzátartozóik, szüleik elvesztését. Ez a tapasztalat, arányait tekintve, a depresszió, öngyilkossági kísérlet miatt kezeltek körében megfigyeltekhez hasonló [9]. Ezt a jelenséget árvaságeffektusnak (orphanhood effect) nevezik [15]. A szüleiket korán elvesztett gyermekeknél szociális izoláció jöhet létre, amelyből a szociális konvenciókon való túllépés képessége fejlődhet ki [7]. Az árvaságeffektus különösen erôs lehet írók körében: egy vizsgálat $55 \%$-os gyakoriságot talált [9]. Kreatív személyekkel való interjúi során Csikszentmibályi [16] az apa elvesztésének visszatérő témáját észlelte, és ennek alapján arra a következtetésre jutott, hogy bár a szülők korai elvesztése negatív következményekkel járhat, ilyenkor a gyermeknél a felnőttekre jellemző felelősségtudat kialakulása a megszokottnál korábban következik be.

Johann Sebastian Bach árvasága mellett Charlotte, Emily és Anne Brontë is korai gyermekkorukban veszítették el édesanyjukat és idősebb nővérüket [17], majd maradandó írói életmúvet hoztak létre.

Edvard Munch norvég festő ötévesen veszítette el édesanyját, majd egyik nővérét, később apját és egyik öccsét. 1908-ban bekövetkezett összeomlásáig és pszichiátriai kezelésének megkezdéséig a gyászfeldolgozás festészeti kísérlete végigvonul egész életmüvén. Festményein a szorongásos zavar és pánikroham ábrázolása mellett a gyász témái jelennek meg: Beteg gyermek (188586), A halál és a lányka (1893), Halottas ágynál (1895), Halál a betegszobában (1895), Halott anya és gyermeke (1897-99). Anyja halálát indulattal élte meg („elhagyták”); ezt az indulatot a nőkre vetítve vásznain a nőket agresszornak ábrázolja (Salome, Charlotte Corday). Partnerkapcsolatai is sikertelenek voltak. Tulla Larsennel való kapcsolatának végkifejletében pisztolybaleset éri: a nővel való dulakodás közben egy pisztoly véletlenül elsült, bal keze mutatóujját operálni kellett. Fantáziájában, önmagát beteljesítő jóslatként, a Nő valóban agresszorrá vált. Erről egy képsorozat tanúskodik: Önarckép a mütóasztalon (1902), Gyilkos (1906), Marat halála (1907, két változatban). Soha nem nősült meg [18]. A szorongás, a gyász externalizálása, a festővászonra való átültetése nem gyógyította meg Munchot; 1908-ban súlyos, alkoholizmusával összefüggő delíriumközeli állapotban került a koppenhágai pszichiátriai klinikára, ahol - féléves gyógykezelés után - vált tünetmentessé.

René Magritte (1898-1967) belga szürrealista festő következetesen olyan motívumokkal látja el képeit, ame- lyek édesanyja, Régina öngyilkosságához, az anya elvesztésének traumájához kapcsolódnak. A trauma kibeszélése helyett annak "kifestését” választotta („gyúlölöm a múltamat és mások múltját”). Egy ízben személytelen távolságtartással írt anyja haláláról: „Elhagyta legkisebb gyermekének szobáját, s a gyermek éjféltájt észrevette, hogy egyedül maradt. Riasztotta a családot. Az apa és a fiúk hasztalan kutatták át a házat, amikor valaki észrevette, hogy az ajtótól lábnyomok vezetnek a hídhoz. Az aszszony itt vetette magát a vízbe, s mire megtalálták, fejét beborította hálóinge. Soha nem tudták meg, vajon ő fedte el arcát a félelmetes halál előtt, vagy az áramlás vonta be a lepellel." A legtöbb kép, amely az anya elvesztésére vezethető vissza, ugyanabban az évben, 1928-ban készült. E képek közül kiemelkedik $A$ lehetetlen megkisértése, amelyen egy öltönyös férfi, a festő, az eredeti, mitológiai történet szerint a „szobrász" (Pygmalion), éppen szobrot fest, egy meztelen nő szobrát. A Pygmalion-történet ismeretében a képet vágyteljesülésnek tekinthetjük, a halott anya támad fel a „szobor” megelevenedésével. A fenyegetett gyilkos címú festmény (1926) réteges kompozíciójában a festő anyja elvesztésének története elevenedik meg: a kép középpontjában egy női holttest nyúlik el egy kereveten, lepellel a nyakában, a halott körül kalapos és hajadonfött férfiak, az egyik kalapos kezében bunkó, a másik kezében halászháló [19].

Magritte fő gyászmotívuma a lepel, amely a képeken látható figurák fejét takarja el (Középponti történet, Az élet fölfedezése, Szerelmesek, Szimmetrikus ravaszság). A lepel megjelenik azon az aktábrázoláson is, ahol a fej hiányzik (Éjszakai életkép), vagy egy halott fej helyettesíti az élőt (A kontár). Máshol halott emberi test lebeg a folyó közelében sétáló keménykalapos férfi mögött (Egy magányos sétáló álmodozásai). Az emlékezet és a Mélyvizek című festményeken a halott anya arca látható. A Filozófia a budoárban címú kép központi témája egy szekrénybe akasztott hálóing. A hálóingen egy női test idomai türemkednek ki. A festő kalapos önábrázolásai is anyjához kapcsolódnak: anyja kalapkészítő volt. A kalapos képek nagy részén maga a festő látható, aki egész életében kalapot hordott. Mintha „kalapból húzták volna elö”. Vagy, ahogy ő fogalmaz: „Nekem is van egy keménykalapom; nem vágyom különösebben arra, hogy kitünjek a tömegböl.”

Szemben Munch-kal, Magritte - részben a festészet eszközeivel, részben partnerválasztásával (múzsája és alkotótársa, Georgette Berger egész életén át hű és odaadó partnernek bizonyult) - hatékonyan dolgozta fel gyermekkori traumáját, nem vált pszichiátriai beteggé, és kiegyensúlyozott, sikeres életet élt.

\section{Életveszélyes helyzetek túlélése}

Mezei Ottó korabeli Csontváry-írások alapján kimutatta, hogy 26 évesen a szegedi árvíz során átéltek Csontváry számára halálközeli élményt jelentettek, és ezt az élményt gyermekkori traumák alapozták meg. Példának az 
iskoláskorában megtapasztalt üstökösélményt, egyik nővére korai, tûzvészben lelt halálát és három gyermekkori „halálpróbát” (csatornába ugrás, később elsült fegyver csövével való szilvaszedés, veszett kutyával való kontaktus) említ. A szegedi kataklizmát mintegy megelőzte egy húszéves korban történt kaland, amikor csaknem megfagyott az egyik éjszaka folyamán, mivel a kocsmáros nem engedte be többszöri kiadós zörgetés után. Csak úgy menekült meg társaival, hogy felgyújtották a szalmaboglyát és a tüzénél melegítették fel magukat [20]. Két képe őrzi e traumák emlékét: Hajótörés (1903), amelyen Géricault $A$ medúza tutaja (1818) címú képéhez hasonlóan hajótörést szenvedett emberek nagy kínok közepette várják megmentésüket vagy a halált (3. ábra), és a Zrinyi kirohanása (1903), amelyen égô ház (amelyben nővére odaveszett) előtt Csontváry-Zrínyi áll, aki egyedül tartóztatja fel a török hadsereget (és menti meg nővérét a haláltól), vágyteljesítő fantáziaként.

\section{Erőszaknak, kínzásnak való kitettség}

Ebben a fejezetben a múvészet és erőszak viszonyának csak a traumával összefüggő aspektusát vizsgálom. Amikor az agresszió valamilyen formája megjelenik a festményeken, fel lehet állítani azt a hipotézist, hogy trauma vagy traumasorozat áll a képek hátterében. Alábbiakban az élettörténet által igazolt traumatikus élmények általam vizsgált múvészettörténeti példáiba engedek betekintést.

Egy XVII. században élt festőnő, Artemisia Gentileschi képein visszatérő téma, hogy nő erőszakot követ el férfi ellen (Judit megöli Holofernészt, 1612, 1620, Jábel és Sisera, 1620). Ez az ismétlődő témaválasztás felveti a képek mögött meghúzódó traumatikus élmény lehetőségét. Az élettörténet vizsgálata igazolta a felvetést: Artemisia 19 éves korában, 1612-ben súlyos traumasorozaton ment keresztül. Ebben az évben a múvészeti akadémia elutasította felvételi kérelmét. Ekkoriban nem hitték el, hogy nő is festhet jó képeket. Apja, aki szintén festő volt, egyik festőtársát, Agostino Tassit kérte fel, hogy fejlessze tovább lánya festészetben való jártasságát. Néhány hónappal később kiderült, hogy Tassi megerőszakolta a szép szűz lányt. Ekkor az apa feljelentette Tassit és hosszú bírósági procedúra kezdődött. Bár a traumairodalomban a per kialakulását a trauma gyógyításának egyik első lépéseként tartják számon [21], Gentileschi esetében a per újabb tortúrák kezdetét jelentette. A periratok tanúsága szerint élete legfájdalmasabb élményének minden mozzanata nyilvánossá vált. Bábák által végzett nőgyógyászati vizsgálaton kellett átesnie a bíróság szeme láttára. Egy festő számára talán a legnagyobb megpróbáltatás akkor érte, amikor - az akkori szokásoknak megfelelően - hazugságvizsgálatnak vetették alá. Ez abból állt, hogy zsinórral körülfonták Artemisia ujjait, majd egyre erősebben megszorították a zsinórt. Ez a tortúra azon a közhiedelmen alapult, hogy a fájdalom hatására mindenki az igazat mondja. Az eljárás során ismételten megkérdezték tőle, igaz-e, hogy Tassi megerőszakolta. Ô mindvégig kitartott amellett, hogy így történt. Ez a súlyos traumatizáció kimeríthette a szakirodalomban korábban leírt úgynevezett „kínzásszindrómát” (torture syndrome) [22, 23]. S bár a bíróság Artemisiának adott igazat, s nem sokkal a per után a festőnő férjhez ment és öt gyermeket szült, lelke még nyolc évvel a trauma után sem nyugodott meg, a Judit/Holofernész témát újra és ugyanolyan horrorisztikus módon festette le [24].

Csontváry Kosztka Tivadar családi nevelése az erőszakos porosz nevelési stílus iskolapéldája. A pszichiáter Pertorini Rezsó a családi és gyermekkori adatok között - Csontváry önéletrajzára hivatkozva - megemlíti, hogy Kosztka László „a gyermekeket szigorúan nevelte, kópéságaikért könnyen lábszíjra kerültek"; „a sportban természetesen a Kosztka fiúk vezettek, s ha hiba esett, ók lettek elnadrágolva, s a sötét pincébe zárva" [25]. Az egyik legdurvább verés akkor következett be, amikor Csontváry hatéves korában az első iskolai tanítási napon vitába szállt a tanárral, aki azt magyarázta éppen, hogy Isten hat nap alatt teremtette a világot. A kis Csontváry ezt kétségbe vonta, mondván, hogy a világ olyan bonyolult, hogy nem lehet ennyi idő alatt létrehozni. Nemcsak a tanár verte meg brutálisan, hanem az apja is, amikor megtudta, mi történt. Három napot töltött a házuk alatti pincében, és csak vizet kaphatott. Tekintélyproblémája végigkísérte életét. Egóját kitágítva egyrészt a „legnagyobb festónek” képzelte magát, „nagyobbnak Raffaelnél”, másrészt az Istennel és a császárral egyenrangúnak tartotta magát. Ezért is lett festő: felfogása szerint festészetével ugyanazt tette, mint az Isten, folyamatosan újrateremtette a világot. Az erószak problémájával egy képe foglalkozik, Az öreg halász (1902).

Gulácsy Lajos anyja a szemtanúk szerint merev, hideg, korlátolt, rosszindulatú nő volt, aki zsarnokoskodott fia felett. Az apa halála (1904) után Gulácsy klinikai felvételéig (1917) egyre szorosabb szimbiózisban éltek és egyre súlyosabb konfliktus alakult ki közöttük. Az anyai agreszszióra a festő viszontagresszióval válaszolt, verekedéseik egyre durvább méreteket öltöttek. Pszichiátriai kezelésére is emiatt és nem autisztikus viselkedése miatt került sor. Agresszív témaválasztásaiban (több grafikáján Salome Keresztelő Szent János levágott fejét tartja a kezében, amely Gulácsy arcára emlékeztet) a nő agresszorként, Gulácsy áldozatként jelenik meg, az anyai agresszió tükrözéseként (4. ábra). Egy anekdota szerint, amikor azzal támadták barátai Gulácsyt könnyưvérü nők társaságában, hogy nem tud bánni a nőkkel, így védekezik: „Ezt nekem nem lehet mondani. Nagyon is tudnék én Pintyőkével bánni. Ha én megcsókolnám, vért szívnék az ajkáról és korbáccsal ütném. Addig korbácsolnám, míg a vér patakokban folyna róla" [13].

\section{Háborús trauma}

A mûvészek különösen érzékenyek a szélsőséges történelmi helyzetekre, a háború is ezek közé tartozik. Voltak 


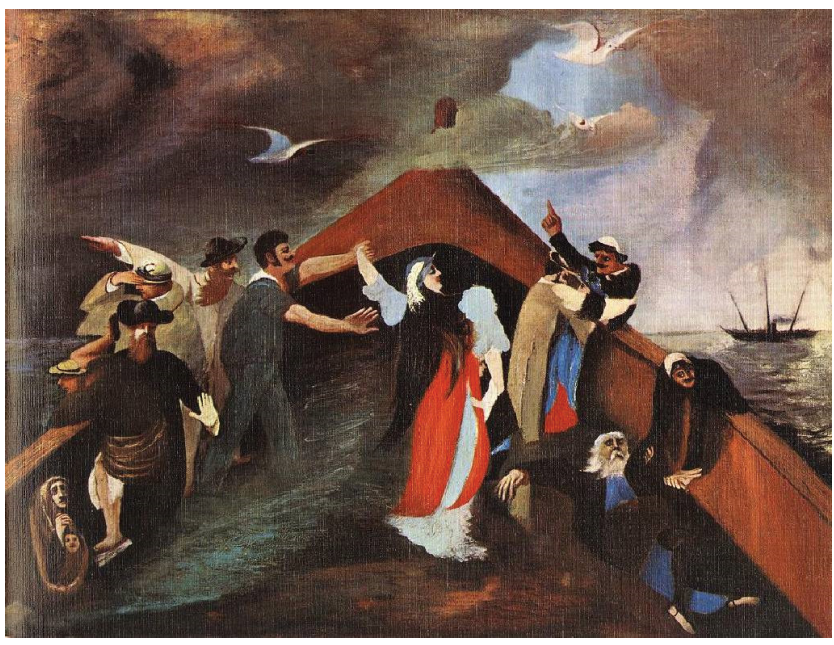

3. ábra

| Csontváry Kosztka Tivadar: Hajótörés, 1903

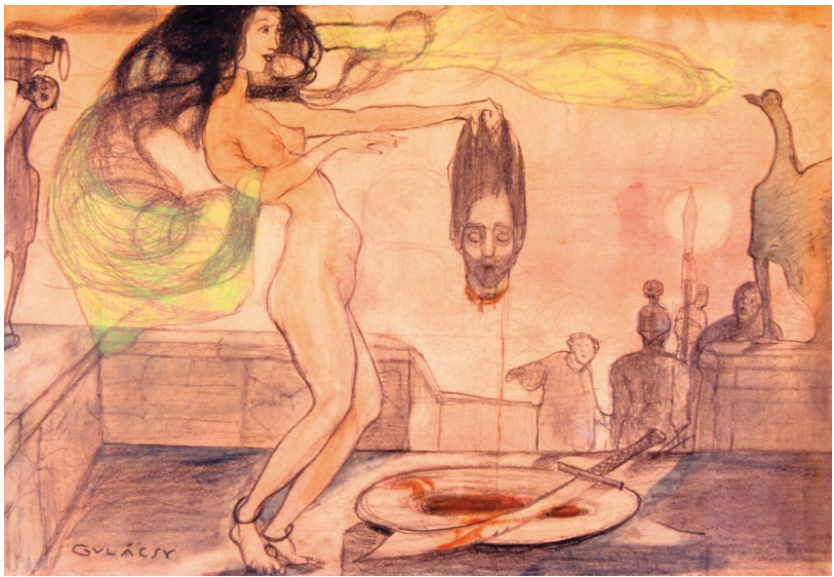

4. ábra

| Gulácsy Lajos: Salome, 1908-1909

mưvészek, akik háborús előérzettel előrevetítették a később történteket. Franz Marc német expresszionista festő 1913-ban megfestette a Szegény háborús Tirol (Das arme land Tirol) címú képét, majd festett egy farkasfalkát is, és a képnek a Balkáni háború (Balkankrieg) címet adta. Később, a fronton harcolva „vég nélküli, szeretet nélküli háborúról” írt egyik levelében, amelyet a háborúban elhunyt festőbarátja, August Macke özvegyének írt, majd így folytatta: ,...gondolataim pillanatnyilag a semmiben járnak, nyugtalanok és terméketlenek, tele vannak gyülölettel a háborúval szemben, és ami különösen hátborzongató ebben az állapotban, hogy egyre jobb katona lesz belölem! Gyakran nem ismerek magamra: különös fajzat vagyunk mi, férfiak. A háború, sajnos, egyre férfiasabbá tesz bennünket. Az utóbbi időben már elképzelni is alig tudom magukat, nőket...” Később egy gránátszilánk fúródott a fejébe és meghalt $[26,27]$. Ernst Barlach a háború elején zuhanó, bosszúálló angyal szobrát faragta ki, Otto Dix pedig 1914-ben, szintén a háború elején, festett egy önarcképet, amelynek azt a címet adta: Önarckép, mint céltábla.
A háborúra adott szélsőséges válaszok a művészek részéról a háború apoteózisától a harcos pacifizmusig terjedtek. A futurista Filippo Marinetti még jóval a háború előtt kijelentette, hogy „a báború a világ egyetlen megtisztítója”. Számos festő és író - határtalan naivitással - lépett be önként a hadseregbe, bár nem azonos indíttatásból. Amedeo Modiglianinak ez nem sikerült; a sorozáson tüdőbaja miatt alkalmatlannak minősítették, ezt követően krízisbe került, amelyet alkohollal és hasissal próbált oldani [28]. Guillaume Apollinaire költő francia identitását erősítendő lett katona, majd háborús sérülése miatt szerelték le, s a sérülés következményeibe halt bele évekkel később. Oskar Kokoschka Alma Mahlerrel való szakítása feldolgozására igyekezett háborús részvételét felhasználni, de fej- és tüdősérülése, illetve súlyos lelkiállapota miatt leszerelték.

A lelkiállapot súlyossága több múvészt késztetett arra, hogy felhagyjon a háború iránti lelkesedéssel, például Max Beckmann és Ernst Ludwig Kirchner, mindketten pszichotikusok lettek. Kirchner 1915-ben a Tüzérek címü festményén a katonák kiszolgáltatottságát ábrázolta hatásos expresszivitással: vékony, sárgás színű meztelen katonák láthatók a képen, akiket „acélosan éles vízsugarak bombáznak a közös zuhanyozóban”. A jobb oldalon álló tiszt egyenruhát és térdig érő csizmát visel [26]. Max Beckmann önkéntesként jelentkezett kórházi szolgálatra. Kezdetben őt is elragadta a hazafias lelkesedés, de már szolgálata elején kijelentette, hogy „nem fogok löni a franciákra, hiszen annyit tanultam tölük, az oroszokra sem, mert Dosztojevszkij a barátom”. Egy évvel később „idegösszeomlás” miatt a szolgálatot nem tudta folytatni. 1919-ben egyik levelében azt írta, hogy „képeimmel szemrehányást teszek Istennek mindazért, amit elrontott”. Nyers víziókkal próbálta a háború nyomán keletkezett életérzését kifejezni [27].

Több múvész viszont kezdettől viszolygott, sőt irtózott a háborútól (Käthe Kollwitz, George Grosz). Kollwitz traumáját súlyosbította, hogy fiát megölték a háborúban. A háború után hét fametszetből álló drámai sorozatot készített $A$ háború címmel. Grosz elemi gyúlölete a háború iránt (szerencsére jól gyógyuló) pszichózisba torkollott. Keserü és ironikus rajza - KV: Hittel gyógyítók - „indulatos vádirat a háború örültsége, a bürokratikus hadigépezet embertelensége és müködésének abszurditása ellen” (1918). Joviális katonaorvos vizsgál egy szemüveges holttestet, amely már felbomlásának előrehaladott stádiumában van, és kijelenti: „KV”, azaz katonai szolgálatra alkalmas. Amikor kijött az elmegyógyintézetből, ezt írta egyik barátjának: „Jelenleg egy hatalmas képet festek a Pokolról-groteszk figurákkal és holdkórosokkal zsúfolt sikátort, amelyben rengeteg dolog történik - baloldalt maga az ördög lovagol lefelé egy koporsón, jobboldalt egy fiatalember öklendezik, és okádja bele a vászonba az ifjúság minden csodálatos illúzióját. Oskar Panizzának [egy pszichiáternek - G. J.] ajánlottam a képet. Megszállott emberi állatok tömege..." Nem sokkal a háború 
után Grosz halálnak öltözve kezdett feltünni a berlini utcákon [26].

A fiatalon elhunyt Georg Trakl osztrák költő Grodek címú utolsó verse is azokat a tapasztalatokat tükrözi, amelyeket Lengyelországban, egészségügyi szolgálat során szerzett: „Este gyilkos fegyperektől dübögnek/az oszi erdök, aranyló rónák/s a kék tavak, fölöttük a Nap/komoran gördül tova, haldokló harcosokat,/szétzúzott szájuk jajgatását ölelik az éjjel...” (Erdélyi Z. János fordítása).

Gulácsy Lajos 1914 augusztusában, a háború hírére vált pszichotikussá. Néhány nap alatt üldözéses téboly jelei mutatkoztak nála, hallucinációk hatására menekülni kezdett vélt kivégzése elől; többször öngyilkosságot akart elkövetni. Ekkor került sor első elmegyógyintézeti kezelésére Velencében. Háborús vízióit grafikákon és festményeken örökítette meg [13].

Otto Dix egész életmúvére rányomta a bélyegét mindkét világháború. Munkásságában a háborúhoz való viszonya a heroizmustól a pacifizmusig széles skálán mozog. 1914-ben a céltáblás önarcképe mellett több olyan önarcképet festett, ahol harcias, gyilkos figuraként jelenik meg, a háború istene, Mars vörös színeiben. Előreszegezett kopasz feje elszánt erôt és érzéki brutalitást sugall. Végigszolgálta a háborút, érdemeiért vaskeresztet kapott. Két könyvet vitt magával a harctérre, a Bibliát és egy Nietzsche-kötetet. A rombolás képei, letarolt harcmezők ragadták meg. A háború után, 1920-ban megfesti a Skatjátékosok címü képét, amelyen az alsó végtagok nélkül kártyázó figurák könyörtelenül mutatják be a háború súlyos következményeit. 1924-ben Goya $A$ háború borzalmai címü grafikasorozatára emlékeztetően hasonló sorozatot rajzol $A$ báború címmel. Még a harmincas években is vissza-visszatér a háború témájához: Háború címmel Bosch múveire emlékeztető monumentális triptichont fest, a keresztre feszítés motívumaival. Egy interjúban 1963-ban a frontszolgálatra így emlékszik vissza: „Ébeztünk, rettegtünk, a nadrágunkba piszkitottunk.” Amikor megkérdezték tőle, miért jelentkezett önként, így válaszolt: „Személyesen kellett megtapasztalnom, hogy milyen az, amikor valaki közvetlenül mellettem boltan esik össze... Mindenröl meg kellett gyözödnöm, maradéktalanul és a végletekig. Ezt akartam. Igy azután bizonyosan nem vagyok pacifista. De lehet, hogy furcsa ember voltam. A saját szememmel kellett látnom az egészet. Ilyen realista vagyok” [26].

\section{Baleset, betegség}

Henri de Toulouse-Lautrec francia festő 13 éves korában a jobb combcsontját törte el, majd egy évvel később a balt. A törések egy ismeretlen eredetü, genetikailag megalapozott congenitalis csontbetegség miatt nem gyógyultak rendesen, testi fejlődése visszamaradt. Testmagassága mindössze $152 \mathrm{~cm}$ volt, és teste erősen aránytalan: a törzs méretei megfeleltek egy egészséges felnőtt törzsméreteinek, de végtagjai feltűnően rövidek, kezei, lábai kicsik, ujjai tömpék. Koponyáján a kutacsok nem záród- tak tökéletesen, ezért abnormális nagyságúra nőtt. Orvosi tanácsra mindig kalapot viselt, a szakállával pedig az álla fejletlenségét próbálta takarni, ami szintén a betegség jele. A modern gyógyászat ezt a betegséget pycnodysostosisnak (tömöttcsontúság) vagy Toulouse-Lautrecszindrómának nevezi. Ez a fizikai betegség a csontokat törésre hajlamosítja, és számos pszichés trauma csatlakozik hozzá: nem tudott a kortársaihoz és a nemesi származásúakhoz hasonló életet élni, mozogni, lovagolni, vívni, illetve a nők rendre visszautasították közeledését. Ez a baleset által közvetített betegség egész életére rányomta a bélyegét, a társadalom perifériájára került, alkoholbeteg lett, és vérbajt kapott. E betegségek szövődményei miatt viszonylag fiatalon halt meg. Önábrázolásaiban ugyan - hưvös távolságtartással - megjelenik törpesége, de közvetlenül soha nem mutatta meg traumájával öszszefüggő lelkiállapotát [10].

Frida Kahlo gyermekparalízisben betegedett meg, apja kilenc hónapig ápolta, lábfeje deformálódott. Nadrággal, majd hosszú szoknyával próbálta palástolni fogyatékosságát. Ennek ellenére „bicebóca Fridának” csúfolták. Tizennyolc éves korában autóbusz-baleset áldozata lett. Frida szavaival, „Különös ütközés volt ez, nem heves, hanem tompa és lassú. Mindenki megsérült, én súlyosabban..." Frida teste szétroncsolódott, súlyos csípő- és gerincsérülést szenvedett, jobb lába is megsérült [10]. Túlélte a balesetet, és szívóssága, életereje, valamint számos mútét segítette hozzá ahhoz, hogy három évvel a balesetet követően talpra álljon. A mưvészi tevékenység egész életében eszköz volt a kezében a betegség, illetve annak következményei (depresszió, alkoholprobléma) elhatalmasodása ellen. Gerincdeformitásai megakadályozták terhességei kihordását, spontán és múvi abortuszai másodlagos traumaként súlyosbították pszichés állapotát. Abortuszábrázolásai, ahogy aktuális lelkiállapotának más képi megnyilvánulásai is, megrázóak. Képeinek több mint fele önarckép: a kreativitás-szakirodalomban esetét hozzák fel a spontán rajzolás és festés öngyógyító hatása példájának [5].

Lovis Corinth a königsbergi akadémián, Münchenben és Párizsban tanult. Naturalista portrékat, tájképeket és enteriőröket, csendéleteket festett. 1900 és 1911 között impresszionista stílus volt rá jellemző, 1912-ben jobb féltekét érintő stroke-on esett át, bal oldali végtagbénulással. Felesége gondos ápolása következtében újra kezdett járni és festeni, és ettól kezdve minden nap rajzolt a zürichi egyetem kórházában. Megváltozott a művészete, az impresszionizmust expresszionizmus váltotta fel (annak ellenére, hogy korábban elutasította azt), egyre érzékenyebbé vált az emberi dolgok, érzelmi kérdések, az emberi szenvedés iránt. Ekkor festette legszuggesztívebb képeit: Vak Sámson (1912), Vörös Krisztus (1922) (5. ábra), Ecce homo (1925). Önarcképsorozatban elemezte, képileg dokumentálta állapotának változásait. „Egészséges” önarcképein az arcok a nézővel szembenéznek, a „beteg” arcok félig elfordulnak, az arc nem a nézőre tekint. Az arc bal oldala elhanyagolt, elnagyolt, 
téri deformitásokat mutat. 1908-ban festette Charlotteról, feleségéről $A$ fekete álarc címü képet. Ugyanez a téma jelenik meg az 1924-ben festett Carmencita címú képen. Érdemes megfigyelni a két festmény közötti különbséget. A különbség jól demonstrálja, hogy a realista stílus hogyan csap át expresszionista stílusba [29].

Otto Dix német festő már 1927-ben a drezdai múvészeti akadémia professzora lett. Pályakezdőként naturalisztikus-realisztikus stílus jellemezte. Az első világháború mélyen érintette, stílusa megváltozott, festészete fanyar, karikaturisztikus lett. Később az expresszionizmus és a szürrealizmus között ingadozott. A nácik múvészetét degeneráltnak bélyegezték, emiatt emigrált, a Bodensee partjára költözött és itt élt haláláig. 1967-ben jobb féltekei stroke lépett fel nála bal oldali végtagbénulással. Három napig képtelen volt rajzolni, majd a negyedik naptól kezdve elkezdett újra rajzolni és festeni, és ettől kezdve minden nap rajzolt a zürichi egyetem kórházában. Egy héttel később rajzain a bal oldali aszimmetria rendeződött. 1968-ban lázas önarcképsorozatba kezdett. Az első kép még hasonlít önmagára, bár a térviszonyok és az arcstruktúra torzult, a jobb oldali csukott szem előreesik, protrudált. A késóbbi képeken már nem felismerhető az alkotó. Az egyik, karikatúrának túnő önarcképén, amelyen toll van a festő kezében, az eltakarja az arc alsó részének jelentős részét. A jobb kéz több mint öt ujjból áll, ez a sokujjúság más képeken is látható. Haláláig litográfiákat készített, majd a második stroke a halálát okozta. Egyik méltatója szerint a halála előtt készült képek „kényszeres önvizsgálódást tükröznek” [30].

\section{Szerelmi frusztráció}

A szerelem egyoldalúvá válása, az egyik vagy mindkét fél szakítása, illetve a beteljesületlen szerelem korábban nem tudatosult vagy tudatosan átélt gyermekkori traumák sebeit tépheti fel. Két példa illusztrálja a művészek szerelmi frusztrációjának feldolgozásmódját, Oskar Kokoschka és Hans Bellmer példája.

Oscar Kokoschka 1912-ben ismerkedett meg és bonyolódott szerelmi viszonyba az elegáns nagyúri társaságba tartozó, nagypolgári zsidó családból származó és tizenkét évvel idősebb Alma Mahlerrel. Kapcsolatuk három évig tartott. Alma - naplója tanúsága szerint - egyre fojtogatóbbnak élte meg Kokoschka birtokló, kisajátító, a társasági élettől őt elzárni igyekvő attitűdjét, és bár terhes lett a festőtől, miután terhességét múvi úton megszakíttatta, elhagyta Kokoschkát. Ekkor tört ki a világháború, Kokoschkát behívták, majd megsebesült. Halálhírét keltették, és ez kapóra jött az asszonynak a szakításhoz, és ahhoz, hogy egy éven belül feleségül menjen Walter Gropius építészhez. Kokoschka súlyos narcisztikus krízisét a háború átélt borzalmai sem tudták feloldani, más megoldást kellett találnia. A müterme falát feketére festette, papagájt vásárolt, akinek féltékeny ragaszkodása Almára emlékeztette. Az „Alma-probléma végső megoldására" készíttetett magának egy minden részletében tö-

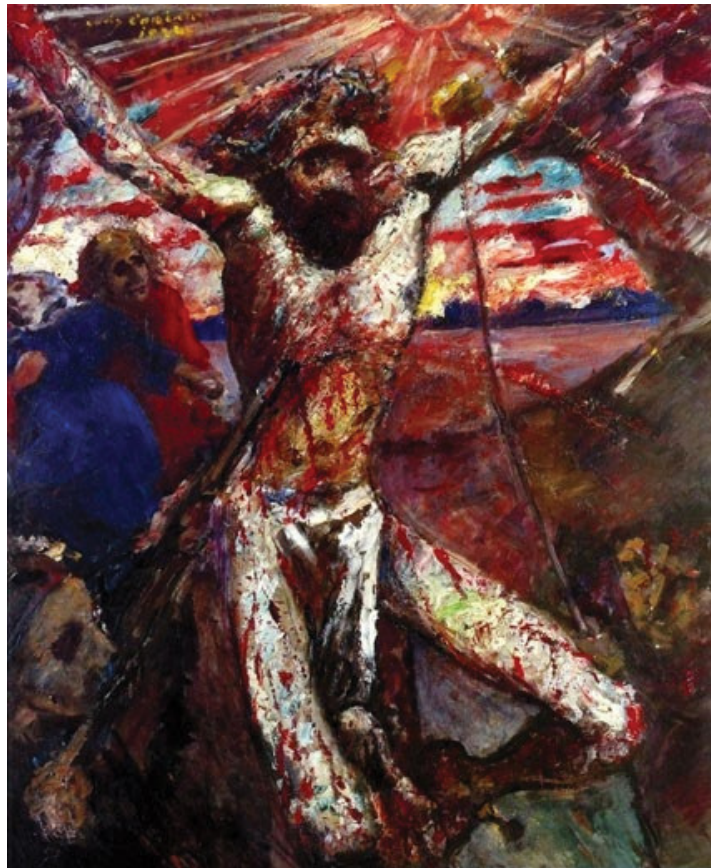

5. ábra

| Lovis Corinth: Vörös Krisztus, 1922

kéletesen élethú Alma Mahler-babát, amelyet partnerként kezelt, az operába, sétakocsikázásra és társaságba is magával vitte. Végül egy ünnepség során rituálisan is „megölte” a babát, Kokoschka ekkor végleg kigyógyult a szerelmi traumából, és megnősült. Szerelme történetét festményeken és az Orpheusz és Eüridike címú drámájában is feldolgozta. A drámát 1923-ban mutatták be, a bemutatón Alma Mahler is részt vett [31].

1930-ban Hans Bellmer lengyel származású német és francia festő, grafikus, fényképész fiatal felesége, Margarete tuberkulózisban betegedett meg, majd néhány évvel később meghalt. Felesége haldoklása idején Bellmer beleszeretett az éppen akkor Berlinbe utazó unokahúgába, a tizenöt éves Ursulába, aki visszautasította közeledését. Két évvel később feleségét, bátyját és unokahúgát elvitte Offenbach Hoffmann meséi címü előadására. Olympia baba története által felvillanyozva - Ursulához füződő frusztrált érzelmei és gyermektelensége egyfajta „megoldásaként” - Bellmer úgy döntött, hogy készít magának egy háromdimenziós babát. A babát ugyanaz a Lotte Prinzel készítette el 1933-ban (Hitler hatalomra jutása idején), aki Kokoschka babáját is megalkotta. A babát Bellmer fotókkal dokumentálta, és rövid elemzést is készített hozzá, majd 1934-ben $A$ baba címmel könyv formájában megjelentette. Később más babákat is készített; a „babaprobléma” végigkísérte életét [32].

\section{Megbeszélés}

A leírt traumaábrázolások a következő jellegzetességeket mutatják: A Nap visszatérő jelenléte a múvészi tevékenységben érzelmi deprivációra, szülői elhanyagolásra utalhat. Az anyaproblémán való „rágódás”, a problematikus 
anyakép, anyatéma ismétlődő, visszatérő jellege az életmúben szintén érzelmi nélkülözésre enged következtetni. Az elvesztett személy közvetlen vagy közvetett, a személyhez tartozó szimbólumokon keresztül megnyilvánuló jelenléte egy adott alkotói periódusban vagy az életmú egészében elhúzódó gyászt tükröz. A tökéletesre duzzadt szelf ábrázolása, illetve a müvészi tevékenységben való megnyilvánulása tekintélyproblémát, az apai agresszió lereagálását jelentheti. Erőszakos vagy erőszakra jelképesen utaló, gyakran mitológiai jelenetek visszatérô ábrázolása a múvész áldozattudatára, viktimizációjára utalhat. A háborús trauma múvészek egy törékeny csoportjánál átmeneti vagy később tartóssá váló pszichotikus megbetegedést facilitálhat. A háborús traumák szürreális víziókban vagy maró iróniára, érzelmi távolságtartásra utaló képekben nyilvánulhatnak meg. Baleset/betegség traumája érzékennyé teheti a múvészeket az emberi szenvedés iránt, és ez stílusváltást is előidézhet az életmúben. A betegség előrehaladása folyamatos, olykor kényszeres önvizsgálatra, állapotuk monitorozására késztetheti az alkotókat, önarckép/önábrázolás sorozattal. A kapcsolatmegszakadáshoz kapcsolódó gyászmunka a szeretett személy tárgyszerú alteregóját hívhatja elő bábu, baba vagy más tárgy formájában, az elveszített vagy nem megtalált személy átmeneti vagy tartós helyettesítéseként.

A vizsgált kreatív viselkedésmódok aszerint is különböznek egymástól, hogy a múvészi tevékenység mennyire járult hozzá az adott trauma hatékony feldolgozásához. Egyes múvészeknél a hatékonyság jól nyomon követhető (Bellmer, Kokoschka, Magritte, Ernst, Corinth), másoknál átmeneti vagy tartós regresszió figyelhető meg (Munch, Gulácsy), míg vannak olyan múvészek, akik kreativitásuk „átprogramozásával” és pszichiáterek segítségével váltak képessé arra, hogy az eredeti traumákon, illetve az azokból fakadó pszichopatológiai állapoton, szerfüggőségen túljussanak (Munch). Alkotó múvészek traumatikus élményeinek és kreativitásának összefüggései hozzásegíthetnek ahhoz, hogy jobban megértsük a traumára adott kreatív válaszokat, illetve a múvészet alkotókra tett hatásainak lehetséges alternatíváit.

Anyagi támogatás: A tanulmány megírása anyagi támogatásban nem részesült. A szerző a közlemény végleges változatát elolvasta és jóváhagyta.

Érdekeltségek: A szerzőnek nincsenek érdekeltségei.

\section{Irodalom}

[1] Wethington, H. R., Hahn, R. A., Fuqua-Whitley, D. S., et al.: The effectiveness of interventions to reduce psychological harm from traumatic events among children and adolescents. Am. J. Prev. Med., 2008, 35, 287-313.

[2] Ferenczi, S.: Trauma in psychoanalysis. [A trauma a pszichoanalízisben.] Gyógyászat, 1934, 71, 20. [Hungarian]
[3] Csubai, Cs. K.: Trauma and repetition. Psychoanalytic aspects of posttraumatic stress disorder. [Trauma és ismétlés. A poszttraumás stresszbetegség pszichoanalitikus szemmel.] Pszichoterápia, 2003, 12(1), 17-28. [Hungarian]

[4] Hatpani, A.: Psychology of trauma in the psychoanalysis. [A trauma lélektana a korai pszichoanalízis tükrében.] Available from: https://uni-eszterhazy.hu/public/uploads/hatvani-andrea-a-trauma-lelektana-a-korai-pszichoanalizis-tukreben_ $56 \mathrm{a} 727 \mathrm{c} 41 \mathrm{e} 0 \mathrm{db} \cdot \mathrm{pdf}$ [Hungarian]

[5] Forgeard, M. J.: Perceiving benefits after adversity: The relationship between self-reported posttraumatic growth and creativity. Psychology of Aesthetics, Creativity, and the Arts, 2013, 7(3), 245-264.

[6] Kaufman, J. C.: The Sylvia Plath effect: Mental illness in eminent creative writers. The Journal of Creative Behavior, 2001, 35(1), 37-50.

[7] Aldwin, C. M., Sutton, K. J.: A developmental perspective on posttraumatic growth. In: Tedeschi, R. G, Park, C. L, Calhoun, L. G. (eds.): Posttraumatic growth: Positive changes in the aftermath of crisis. Erlbaum, Mahwah, NJ, 1998, pp. 43-64.

[8] Joseph, S.: Growth following adversity: Positive psychological perspectives on posttraumatic stress. Psychological Topics, 2009, $18(2), 335-344$.

[9] Simonton, D. K.: Greatness: Who makes history and why. Guilford Press, New York, NY, 1994

[10] Gerevich, J.: Productive desires - Artist and Muses. [Teremtő vágyak - Múvészek és múzsák.] Noran Libro Kiadó, Budapest, 2016. [Hungarian]

[11] Gerbardt, S.: The necessary love - The effect of affects on the development of infant's brain. [A szükséges szeretet - Az affektusok hatása a kisgyermek agyfejlődésére.] Oriold és Társa Kiadó, Budapest, 2012. [Hungarian]

[12] Miltényi, T.: Preface on second edition of Ferenc Lehel: Csontváry. [Előszó Lehel Ferenc: Csontváry című könyvének második kiadása elé.] Szellemkép könyvek 2., Budapest, 1998, 5-33. [Hungarian]

[13] Gerevich, J.: Girl in the cupboard. [Lány a szekrényben.] Osiris Kiadó, Budapest, 2005. [Hungarian]

[14] Kim, S. H., Vincent, L. C., Goncalo, J. A.: Outside advantage: Can social rejection fuel creative thought? [Publication date 2012. Electronic version.] Available from Cornell University, ILR School site: http://digitalcommons.ilr.cornell.edu/articles/613/

[15] Sengendo, J., Nambi, J.: The psychological effect of orphanhood: a study of orphans in Rakai district. Health Transition Review, 1997, 7(Suppl.), 105-124.

[16] Csikszentmibalyi, M.: Creativity: Flow and the psychology of discovery and invention. HarperCollins, New York, NY, 1996.

[17] Barker, J.: The Brontës. Phoenix House, London, UK, 1995.

[18] Gerevich, J.: Pistol shot in the night, or the "death" of Marat. [Pisztolylövés az éjszakában, avagy Marat halála.] Lege Artis Medicinae, 2015, 25(8-9), 398-399. [Hungarian]

[19] Túry, F.: Painting and eternity: The time in the art of Magritte. [Festészet és örökkévalóság: Az idő Magritte művészetében.] Lege Artis Medicinae, 2010, 20(5), 346-348.

[20] Mezei, O.: Documents from the life of Csontváry, I-II. [Csontváry-dokumentumok I-II.] Új Múvészet Kiadó, Budapest, 1995. [Hungarian]

[21] Crawley, K., van Rijswijk, H.: Justice in the gutter: Representing everyday trauma in the graphic novels of Art Spiegelman. Law Text Culture, 2012, 16, 93-118.

[22] Basoglu, M., Jaranson, J. M., Mollica, R., Kastrup, M.: Torture and mental health: a research overview. In: Gerrity, E., Keane, T. M., Tuma, F. (eds.): The mental health consequences of torture. Kluwer Academic/Plenum Publishers, New York, 2001, 35-62.

[23] Kroó, A.: The trauma of torture and the posttraumatic identity. [A kínzás traumája és a poszttraumás identitás.] Imágó, Budapest, 2013, 3[24](3-4), 133-144. [Hungarian] 
[24] Gerevich J.: Revenge with brush and canvas. The trials of a talented woman painter. [Bosszú ecsettel és vászonnal - Egy tehetséges nőfestő kálváriája.] Lege Artis Medicinae, 2015, 25(6-7), 304-306. [Hungarian]

[25] Pertorini, R.: Pathography of Csontváry. [Csontváry patográfiája.] Akadémiai Kiadó, Budapest, 1966. [Hungarian]

[26] Bassie, A.: Expressionism. [Expresszionizmus.] Ventus Libro Kiadó, Budapest, 2006, 141-152. [Hungarian]

[27] Lucie-Smith, E.: Lives of the great twentieth century artists. [XX. századi múvészek élete.] Glória Kiadó, Budapest, 2000.

[28] Gerevich, J.: Volcanic eruptions in Bohemia, or revels of a modest artist. [Vulkánkitörések Bohémiában, avagy egy szemérmes festó tobzódásai.] Lege Artis Medicinae, 2016, 26(3) 144-147. [Hungarian]

[29] Büzner, H. Hennerici, M. G.: Lovis Corinth: Integrating hemineglect and spatial distortions. In: Bogousslavsky, J., Hennerici, M. G. (eds.): Neurological disorders in famous artists - Part 2. Karger, Basel, 2007, 30-43.
[30] Blanke, O.: I and me: Self-portraiture in brain damage. In: Bogousslavsky, J., Hennerici, M. G. (eds.): Neurological disorders in famous artists - Part 2. Karger, Basel, 2007, 14-29.

[31] Gerevich, J.: The silent woman. Story of the Alma doll. [A csöndes asszony, avagy Alma baba története.] Lege Artis Medicinae, 2014, 24(7), 376-379. [Hungarian]

[32] Gerevich, J.: The grip of erotic doll torsos, or the devil of fear. [Erotikus bábutorzók szorítása, avagy a képzelet ördöge.] Lege Artis Medicinae, 2016, 26(4), 226-229. [Hungarian]

(Gerevich József dr., Budapest, Pf. 1216, 1276 e-mail: gerevichjozsef3@gmail.com)

Új fejlesztés az egészségügyben dolgozók, tanulók részére!

\section{A magyar nyelvư szakirodalmi keresőszolgáltatás}

\section{Mi a NOTA? \\ Napivizit Orvosi Tudástár Alkalmazás}

Mit tud a NOTA portál?

Megkönnyíti a magyar nyelvű szakirodalmi források keresését.

Eszköztöl függetlenül, akár okostelefonról, a betegágy mellett állva is használható.

\section{Miben kereshet a NOTA-val?}

Az Akadémiai Kiadó folyóirataiban: Orvosi Hetilap, Magyar Sebészet, Mentálhigiéné és Pszichoszomatika.

Más kiadók magyar nyelvü szakfolyóirataiban: pl. Lege Artis Medicinae, Hypertonia és Nephrologia, Ideggyógyászati Szemle.

A hatályos szakmai irányelvekben.

Magyar nyelvű kérdésekre adott angol nyelvű találatokban, a PubMeden.

\section{nota.hu}

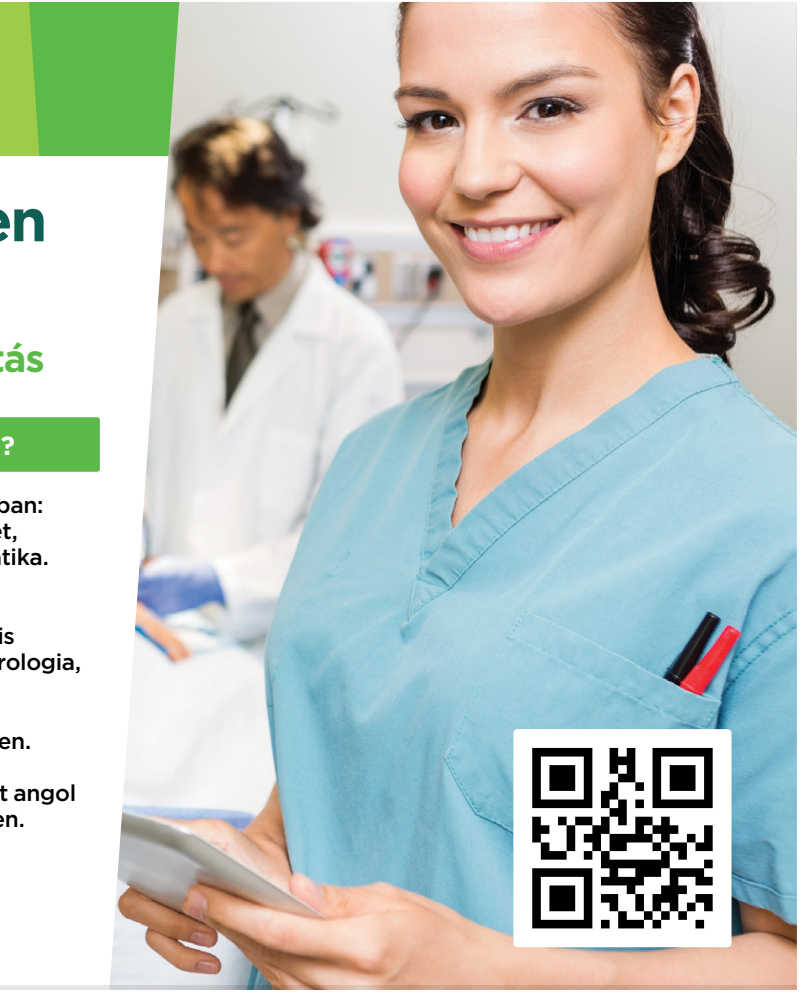

Akadémiai Kiadó

A Wolters Kluwer Csoport tagja

1117 Budapest, Prielle Kornélia u. 21-35. / Telefon: (1) 464-8246

www.akademiai.hu / www.akademiai.com

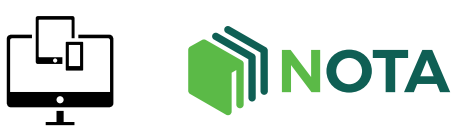

AKADÉMIAI KIADÓ 